\title{
Living Close to Natural Outdoor Environments in Four European Cities: Adults' Contact with the Environments and Physical Activity
}

\author{
Margarita Triguero-Mas 1,2,3,*, David Donaire-Gonzalez ${ }^{1,2,3,4}$ (D), Edmund Seto ${ }^{5}$, \\ Antònia Valentín 1,2,3, Graham Smith ${ }^{6}$, David Martínez 1,2,3, Glòria Carrasco-Turigas 1,2,3, \\ Daniel Masterson ${ }^{6}$, Magdalena van den Berg ${ }^{7}$, Albert Ambròs 1,2,3, \\ Tania Martínez-Íñiguez 1,2,3 [D, Audrius Dedele ${ }^{8}$, Gemma Hurst ${ }^{6}$, Naomi Ellis ${ }^{6}$, \\ Tomas Grazulevicius ${ }^{8}$, Martin Voorsmit ${ }^{7}$, Marta Cirach ${ }^{1,2,3}$, Judith Cirac-Claveras ${ }^{1,2,3}$, \\ Wim Swart ${ }^{9}$, Eddy Clasquin ${ }^{7}$, Jolanda Maas ${ }^{7}$, Wanda Wendel-Vos ${ }^{10}$, Michael Jerrett ${ }^{11}$, \\ Regina Gražulevičienè ${ }^{8}$ (D), Hanneke Kruize ${ }^{9}$, Christopher J. Gidlow ${ }^{6}$ \\ and Mark J. Nieuwenhuijsen 1,2,3 \\ 1 Centre for Research in Environmental Epidemiology (CREAL), ISGlobal, 08003 Barcelona, Spain; \\ david.donaire@isglobal.org (D.D.-G.); antonia.valentin@isglobal.org (A.V.); \\ david.martinez@isglobal.org (D.M.); gloria.carrasco@isglobal.org (G.C.-T.); \\ albert.ambros@isglobal.org (A.A.); tania.martinez@isglobal.org (T.M.-I.); marta.cirach@isglobal.org (M.C.); \\ txerms0@hotmail.com (J.C.-C.); mark.nieuwenhuijsen@isglobal.org (M.J.N.) \\ 2 Universitat Pompeu Fabra (UPF), 08003 Barcelona, Spain \\ 3 CIBER Epidemiología y Salud Pública (CIBERESP), 08003 Barcelona, Spain \\ 4 Physical Activity and Sports Sciences Department, Fundació Blanquerna, Ramon Llull University, \\ 08022 Barcelona, Spain \\ 5 Department of Environmental and Occupational Health Sciences, School of Public Health, \\ University of Washington, Seattle, WA 98195, USA; eseto@uw.edu \\ 6 Centre for Sport, Health and Exercise Research, Staffordshire University, Stoke-on-Trent ST4 2 DE, UK, \\ G.R.Smith@staffs.ac.uk (G.S.); daniel@happia.me (D.M.); G.L.Hurst@staffs.ac.uk (G.H.); \\ n.j.ellis@staffs.ac.uk (N.E.); C.Gidlow@staffs.ac.uk (C.J.G.) \\ 7 Department of Public and Occupational Health, Institute for Health and Care Research, VU University \\ Medical Centre (VUMC), 1007 Amsterdam, The Netherlands; mm.vandenberg@vumc.nl (M.v.d.B.); \\ martin.voorsmit@gmail.com (M.V.); e.clasquin@gmail.com (E.C.); jolandamaas@hotmail.com (J.M.) \\ 8 Department of Environmental Science, Vytauto Didžiojo Universitetas, 44248 Kaunas, Lithuania; \\ adedele@gmf.vdu.lt (A.D.); t.grazulevicius@gmail.com (T.G.); r.grazuleviciene@gmf.vdu.lt (R.G.) \\ 9 Centre for Sustainability, Environment and Health, National Institute for Public Health and the \\ Environment (RIVM), 3720 Bilthoven, The Netherlands; wim.swart@rivm.nl (W.S.); \\ hanneke.kruize@rivm.nl (H.K.) \\ 10 Centre for Nutrition, Prevention and Health Services, National Institute for Public Health and the \\ Environment (RIVM), 3720 Bilthoven, The Netherlands; wanda.vos@rivm.nl \\ 11 Department of Environmental Health Sciences and Center for Occupational and Environmental Health, \\ University of California, Los Angeles, CA 90095, USA; mjerrett@ucla.edu \\ * Correspondence: margarita.triguero@isglobal.org; Tel.: +34-93-214-7311
}

Received: 9 August 2017; Accepted: 21 September 2017; Published: 30 September 2017

Abstract: This study investigated whether residential availability of natural outdoor environments
(NOE) was associated with contact with NOE, overall physical activity and physical activity in
NOE, in four different European cities using objective measures. A nested cross-sectional study was
conducted in Barcelona (Spain); Stoke-on-Trent (United Kingdom); Doetinchem (The Netherlands);
and Kaunas (Lithuania). Smartphones were used to collect information on the location and physical
activity (overall and NOE) of around 100 residents of each city over seven days. We used Geographic
Information Systems (GIS) to determine residential NOE availability (presence/absence of NOE
within 300 m buffer from residence), contact with NOE (time spent in NOE), overall PA (total physical 
activity), NOE PA (total physical activity in NOE). Potential effect modifiers were investigated. Participants spent around $40 \mathrm{~min}$ in NOE and 80 min doing overall PA daily, of which $11 \%$ was in NOE. Having residential NOE availability was consistently linked with higher NOE contact during weekdays, but not to overall PA. Having residential NOE availability was related to NOE PA, especially for our Barcelona participants, people that lived in a city with low NOE availability.

Keywords: green spaces; physical activity; natural outdoor environments

\section{Introduction}

Interest in the health and physical activity (PA)-promoting potential of the physical environment continues to grow [1]. For example, some evidence suggests that the provision of natural outdoor environments (i.e., environments with vegetation like parks and environments with water like the seashore, abbreviated as NOE), the encouragement of certain types of food shops or the measures to reduce traffic density are ecological interventions that can affect health and activity behaviours $[2,3]$.

Such higher level ecological interventions fall under the remit of those in charge of policy and the design and management of our living environments. Yet, there are no clear policy guidelines on the provision of NOE for health benefit that might inform the development of healthy cities. Residential NOE availability has been used as one indicator of whether a city is healthy or not [4-6], but based on limited evidence. Similarly, interest in the diverse urban planning needs of different population groups is increasing. For example, several studies suggest that women, lower-educated, children and elderly may use more NOE close to their residence than other population groups [7-11]. Despite no clear conclusions can be drawn from the existing evidence, usage differences could explain differential health benefits from NOE. Moreover, urbanity degree, ethnicity and location may introduce heterogeneity as well $[9,12,13]$.

This study aimed to address these gaps using objective measures to understand possible associations between residential NOE availability, how much NOE are used, how much NOE are used for PA, and possible links with overall PA levels. We focused on objectively measured exposures and outcomes because we hypothesised that their findings would be more easily translated into policies than findings from subjective measures. Moreover, the use of objective or subjective measures is becoming a recognised cause of inconsistent results. Subjective and objective NOE availability assessments agree moderately [14]. However, the use of one or the other can lead to very different results (see [15] for an example). Similarly, as stated by Hagstromer et al. [16], subjective and objective measures of physical activity assess different things, with subjective measures usually assessing body movement and objective measures usually assessing effort. The correlations between subjective and objective measures of physical activity are usually low-to-moderate $[16,17]$. Usually, subjective measures are considered to be the best system to assess physical activity [16].

\subsection{Contact with Natural Outdoor Environments}

The links between access to and contact with (or use of) NOE is thought to be modified by factors like distance, weather, socio-cultural factors, and perceived safety [18]. Several studies have found that increasing residential NOE availability enhances contact [19-24]. However, to our knowledge, only one study investigated adults' park visits using objective assessment of the NOE contact (specifically GPS-based measures) [25]. Evenson et al. [25] found that their participants spent around $95 \mathrm{~min} /$ week in NOE. Their sample was adults living, on average, around $600 \mathrm{~m}$ (0.4 miles) from a park, as the study focused only on this type of green spaces. So, to our knowledge, no study has evaluated if NOE contact is influenced by residential NOE proximity in adults using objective assessment of the NOE contact.

\subsection{Overall Moderate-to-Vigorous Physical Activity}

Regular PA prevents premature death and chronic diseases [26]. NOE could offer the opportunity for PA through providing locations that might be safe, accessible and attractive [2,3]. A review from 
2008 found that parks and recreational settings availability increased PA in most studies, especially walking [27]. However, a 2011 review found that only 20 out of 50 studies reported a positive link between green spaces and PA, of which only three used objective PA indicators, all three focusing on children and using accelerometers to assess PA [28]. Similar no consistent findings were found in a review from 2015 focusing on objectively measured PA in the U.S. [29] that included studies using both accelerometers and pedometers to assess PA. From the 10 studies in adults, just two found positive relationships, another two found mixed results, and the other six found no associations. However, a recent study by Sallis et al. reported that the more parks near the respondents residence, the more physically active the respondents were [30]. Possible explanations for such inconsistent findings include use of different tools both to assess NOE availability [31-39] and PA [40-42], and diversity in study designs and settings $[29,37]$.

\subsection{NOE Moderate-to-Vigorous Physical Activity}

One of the main gaps in the existing literature is that studies have rarely evaluated the actual use of NOE for PA, hypothesizing that PA was linked to NOE PA $[25,37,43]$. However, some findings indicate that NOE PA may be more beneficial to health than PA performed in other environments [44-46]. To our knowledge, only three studies have evaluated the association between residential availability of NOE and NOE PA $[37,43,47]$ in adults, and none of them found relationships between NOE PA and NOE residential availability. In a sample of adults from four different European cities, we aimed to use objective measures to investigate whether residential NOE availability was linked to: contact with NOE, and moderate-to-vigorous PA (overall and in NOE separately).

\section{Materials and Methods}

\subsection{Study Sample}

All participants were adults from a random sample of 3946 people aged 18-75 years in Europe as part of the Positive Health Effects on the Natural Outdoor Environment in Typical Populations of Different Regions in Europe (PHENOTYPE) project $[13,48]$. All 3946 people were invited to participate in this study. The only inclusion criterion was to be able to walk $300 \mathrm{~m}$ on level ground. In the case of Stoke-on-Trent, around half of the participants were from the original random sample and half were boosted through further mail sent to a random selection of households in the area and further opportunistic sampling within the area (for further details on data collection see Table A1). Participants were residents of four different cities: Barcelona (Spain, $n=107)$, Stoke-on-Trent (United Kingdom, $n=92$ ), Doetinchem (The Netherlands, $n=105$ ), and Kaunas (Lithuania, $n=104$ ). Each participant provided written informed consent before taking part and received financial compensation on completion of the study. The study was conducted in accordance with the Declaration of Helsinki. Ethical approval was obtained from the corresponding authority in each city: Clinical Research Ethics Committee of the Municipal Health Care (CEIC PS-MAR), Spain (2012/4978/I); Staffordshire University Faculty of Health Science ethics committee, United Kingdom; Medical Ethical Committee of the University Medical Centre Utrecht, Netherlands; Lithuanian Bioethics Committee, Lithuania (2012-04-30 Nr.6B-12-147).

\subsection{Design}

A detailed protocol was developed and followed in all participating cities. The protocol included instructions on smartphone placement and use. Accordingly, participants wore a smartphone with the CalFit application installed for seven consecutive days between May and December 2013. The smartphones were worn on a belt attached to the waist. Participants were instructed to remove the belt only when performing activities that could damage the smartphone (such as aquatic activities), when sleeping, and when it was necessary to charge the smartphone battery. The open-source CalFit software runs on Android operating system smartphones. CalFit uses the Global Positioning System 
(GPS) receivers in smartphones to collect valid information on location [49]. This information was used to determine the presence/absence of green spaces within a $50 \mathrm{~m}$ circular buffer of the participant location (Appendix A.1. CalFit data treatment). It has been recently reported that the median distance between coordinates acquired with Smartphone and with GPS trackers is $24 \mathrm{~m}$ overall [49]. Consequently, we used $50 \mathrm{~m}$ as a conservative approach to overcome this accuracy, so locations within $50 \mathrm{~m}$ from a NOE were considered to be in a NOE. CalFit uses the accelerometer motion sensor to assess PA intensity and duration and is in good agreement with the information collected with the widely used Actigraph accelerometer (concordance correlation coefficient, CCC, between 0.83 and 0.91) $[49,50]$. In the present study, CalFit was used to determine minutes of moderate-to-vigorous PA (MVPA, $\geq 3$ METs) and time not wearing the smartphone. Episodes of 40 consecutive minutes or more with measures below $0.3 \mathrm{~g}$ in the vertical axis of CalFit were defined as non-wearing times. We investigated weekdays and weekends separately, hypothesising that relationships on days with everyday duties (i.e., working or studying) would be different than on days with available leisure time. For inclusion in analysis of weekdays, participants were required to have worn the smartphone for at least $10 \mathrm{~h}$ per day on three weekdays [50-52]. Similarly, for inclusion in analyses of weekends, $10 \mathrm{~h}$ per day on two weekend days were required. This resulted in a final sample of 350 participants on weekdays (86\%) and 308 on weekend days $(76 \%)$.

\subsection{Measures}

\subsubsection{Exposure}

\section{Residential Availability of Natural Outdoor Environments}

Residential NOE availability was defined as the presence/absence of green spaces within $300 \mathrm{~m}$ of participants' homes. The $300 \mathrm{~m}$ buffer was chosen for consistency with recommended indicators to be used across Europe $[4,6]$, and on evidence that use of NOE might decline at distances greater than 300-400 m [53]. A $300 \mathrm{~m}$ network buffer was created around each participant residential address. To do so, we applied Network Analyst tools (ArcGIS10, Environmental Systems Research Institute (ESRI), Redlands, CA, USA) to the road network, excluding roads that were inaccessible to pedestrians. The presence/absence of green spaces within the buffers was derived from Urban Atlas 2006 [54] for three of the cities, and Top10 NL [55] for Doetinchem. Both used a 1:10,000 scale and minimum represented unit of 0.25 ha (Top10 NL was adapted to be consistent with Urban Atlas). The included NOE categories were urban green space, agricultural land, semi-natural areas, wetlands, and forests.

\subsubsection{Outcomes}

\section{Contact with NOE}

Contact with NOE was defined as daily average time spent in NOE, separately for weekdays and weekend days. This was derived from CalFit-recorded location data; for any given location point within the data recording period, participants were classified as being in NOE if there was a NOE within $50 \mathrm{~m}$. If the point was inside the Urban Atlas city limits, we used Urban Atlas 2006 or Top10 NL (as above). For the all points that fell outside the city boundary, CORINE Land Cover 2006 (CLC2006) was used.

\section{Overall MVPA}

Overall MVPA was based on CalFit-recorded accelerometer data. PA intensity was defined as the ratio of working metabolic rate to a standard resting metabolic rate (i.e., Metabolic Equivalent of Task, MET). We calculated the daily average time spent in MVPA, separately for weekdays and weekend days without MVPA duration restriction, following previous studies [30,56].

\section{NOE MVPA}

MVPA in NOE was derived from CalFit-recorded location points and time-matched accelerometer data. The indicator was calculated as the daily average time spent in MVPA in NOE based on the 
presence/absence of green or blue space within $50 \mathrm{~m}$ of each location point where PA was performed (as detailed under "Contact with NOE"). This was calculated separately for weekdays and weekend days without MVPA duration restriction, following previous studies [30,56].

\subsubsection{Covariates}

We selected the following a priori covariates based on previous literature: gender $[22,30,37,57,58]$, age [22,30,37,57,58], education completed [22,30,58], living with children younger than 11 years old [13], dog ownership [58], sampling season [58], and neighbourhood socioeconomic status (neighbourhood SES) [30,57]. Sampling season information was derived from sampling dates included in the analyses. All the rest of covariates were derived from information collected for a previous phase of the study [48]. As no comparable data between the four cities existed for neighbourhood SES, each city used its own local data [48].

\subsection{Statistical Analyses}

We conducted complete cases analyses separately for weekdays and weekend days without imputing missing data. Linear models were not considered appropriate after examining residual plots, so we fitted logistic regression models with adjustment for covariates to estimate the associations between residential NOE availability and each outcome separately. For our logistic regression models, we estimated goodness of fit with Hosmer-Lemeshow Test and measured predictive power with McFadden's R2. We categorised our outcomes in two categories: value below or above median value of that variable in the city after excluding zeros. Categorised outcomes were: (i) low and (ii) high contact with NOE, (iii) low and (iv) high overall MVPA, (v) low and (vi) high NOE MVPA. Stratified analyses and interaction terms were included between residential NOE availability and (i) gender, (ii) age, and (iii) city to investigate effect modification. Statistical significance was set at $p$-value $\leq 0.05$. R statistical package (version 3.1.0, R Foundation for Statistical Computing, Vienna, Austria) was used to carry out the analyses between 2015 and 2016.

\subsection{Sensitivity Analyses}

\subsubsection{Low Prevalence of Exposure Categories}

Given the low prevalence of some of the exposure categories in Doetinchem (i.e., less than $4 \%$ of Doetinchem participants with absence of NOE at 300 m network buffer), we repeated the main analyses excluding this city to evaluate the robustness of our findings.

\subsubsection{Buffer Type for Abstracting NOE Indicators}

To evaluate the robustness of findings to our selection of $300 \mathrm{~m}$ network buffer, we repeated the main analyses using exposure indicators for $150 \mathrm{~m}$ and $300 \mathrm{~m}$ Euclidean buffers and $500 \mathrm{~m}$ and $1000 \mathrm{~m}$ network buffers.

\section{Results}

\subsection{Sample Characteristics}

Participants differed from the original sample from which they were recruited; they were more physically active in all the cities and more highly educated in Stoke-on-Trent (data not shown). The characteristics of study participants, prevalence of outcomes, and description of indicators of natural outdoor environments are presented in Table 1. The participants of the different cities were statistically significantly different in most of the characteristics, with the exception of gender, living with children younger than 11 years, and neighbourhood socioeconomic status (Table 1, Table A2). 
Table 1. Sample description and intercity comparisons using Kruskal-Wallis/Chi2 test.

\begin{tabular}{|c|c|c|c|c|c|c|}
\hline & Total & Barcelona & Stoke-on-Trent & Doetinchem & Kaunas & $\begin{array}{c}\text { Intercity } \\
\text { Comparison }\end{array}$ \\
\hline Sample (n) & 408 & 107 & 92 & 105 & 104 & \\
\hline \multicolumn{7}{|l|}{ Sociodemographic characteristics } \\
\hline Gender, females $(n(\%))$ & $53.68 \%$ & $46.73 \%$ & $56.52 \%$ & $57.14 \%$ & $54.81 \%$ & \\
\hline Age (years: median (IQR)) & $51.00(26.00)$ & $40.00(23.00)$ & $44.00(29.00)$ & $59.00(16.00)$ & $55.00(23.50)$ & * \\
\hline Living with children $<11$ years old, one or more $(n(\%))$ & $19.90 \%$ & $24.30 \%$ & $25.27 \%$ & $17.14 \%$ & $13.46 \%$ & \\
\hline Dog ownership, yes ( $n(\%))$ & $34.80 \%$ & $23.36 \%$ & $34.78 \%$ & $22.86 \%$ & $58.65 \%$ & * \\
\hline Highest education, university or more $(n(\%))$ & $56.76 \%$ & $54.21 \%$ & $47.25 \%$ & $49.52 \%$ & $75.00 \%$ & * \\
\hline \multicolumn{7}{|l|}{ Neighbourhood SES } \\
\hline Low & $30.39 \%$ & $40.19 \%$ & $23.91 \%$ & $30.48 \%$ & $25.96 \%$ & \\
\hline Medium & $33.82 \%$ & $35.51 \%$ & $35.87 \%$ & $29.52 \%$ & $34.62 \%$ & \\
\hline High & $35.78 \%$ & $24.30 \%$ & $40.22 \%$ & $40.00 \%$ & $39.42 \%$ & \\
\hline Season, autumn $(n(\%))$ & $51.12 \%$ & $36.19 \%$ & $54.35 \%$ & $58.82 \%$ & $55.77 \%$ & * \\
\hline \multicolumn{7}{|l|}{ Residential availability of natural outdoor environments } \\
\hline Presence/absence of green spaces at 300 m network buffer, one or more $(n(\%))$ & $69.12 \%$ & $41.12 \%$ & $73.91 \%$ & $96.19 \%$ & $66.35 \%$ & * \\
\hline \multicolumn{7}{|l|}{ Weekdays } \\
\hline Sample (n) & 350 & 101 & 70 & 93 & 86 & \\
\hline Contact with NOE, high (minutes: median (IQR)) & $41.40(85.50)$ & $14.67(39.00)$ & $32.23(44.31)$ & $114.60(104.33)$ & $40.30(70.19)$ & * \\
\hline Overall moderate-to-vigorous physical activity, high (minutes: median (IQR)) & $88.80(57.58)$ & $101.50(59.50)$ & $74.22(68.28)$ & $90.25(53.50)$ & $82.67(42.89)$ & * \\
\hline NOE moderate-to-vigorous physical activity, high (minutes: median (IQR)) & $7.73(19.25)$ & $4.20(9.40)$ & $4.60(12.31)$ & $21.00(33.80)$ & $8.57(17.70)$ & * \\
\hline \multicolumn{7}{|l|}{ Weekends } \\
\hline Sample (n) & 308 & 90 & 63 & 80 & 75 & \\
\hline Contact with NOE, high (minutes: median (IQR)) & $43.75(122.50)$ & $33.25(94.50)$ & $16.00(33.50)$ & $128.25(119.00)$ & $29.00(102.00)$ & * \\
\hline Overall moderate-to-vigorous physical activity, high (minutes: median (IQR)) & $78.25(59.75)$ & $88.75(54.62)$ & $53.00(61.00)$ & $81.50(55.50)$ & $74.50(58.00)$ & * \\
\hline NOE moderate-to-vigorous physical activity, high (minutes: median (IQR)) & $7.75(24.12)$ & $6.00(15.88)$ & $4.00(10.50)$ & $25.50(31.75)$ & $6.00(19.25)$ & * \\
\hline
\end{tabular}

${ }^{*}$ Statistically significant differences $(p$-value $\leq 0.05)$ according to Chi2 or ANOVA tests. Notes: NOE for Natural Outdoor Environments. For contact with NOE, overall moderate-to-vigorous physical activity, and NOE moderate-to-vigorous physical activity (including both during weekday and weekends), the table is reporting the original data without categorisation. 
Our participants spent just over $40 \mathrm{~min}$ per day in NOE and around $80 \mathrm{~min}$ per day in overall MVPA (Table 1). NOE contact was statistically significantly higher for our Doetinchem participants than for the participants from the other cities (Table 1, Table A2). NOE contact was also higher on weekend days than on weekday in the pooled data and for Barcelona sample (Table A3). Conversely, overall MVPA was higher for our Barcelona participants than for the participants from the other cities during weekdays. During weekends, MVPA was statistically significantly lower for our Stoke-on-Trent sample than our Barcelona or Doetinchem samples (Table 1, Table A2). The pooled dataset and Barcelona and Stoke-on-Trent ones showed that participants spent statistically significantly more time doing MVPA during weekdays than on weekends (Table A3).

Participants spent around eight minutes per day in NOE MVPA, with statistically significantly higher values in Doetinchem than in the other cities (Table 1, Table A2). Participants, therefore, performed around $9 \%$ of their MVPA in NOE. The only statistically significant differences found in the NOE MVPA between weekdays and weekend days, were in the pooled dataset (Table A3).

\subsection{Contact with NOE}

Having NOE in the $300 \mathrm{~m}$ buffer around the residence was statistically significantly associated with more NOE contact during weekdays, both in the pooled analyses and when stratified by age (Tables 2 and 3). When stratified by gender or by city, the relationships only remained by females or for Barcelona participants (Tables 4 and 5). The inclusion of an interaction between residential NOE availability and gender, or age, or city was not statistically significant (Table A4).

\subsection{Overall $M V P A$}

Residential NOE availability was not statistically significantly associated with overall MVPA duration in the pooled analyses (Table 2). This was unchanged when stratified by gender, by age and by city (Tables 3-5). However, on weekend days negative statistically significant links were found for our Kaunas sample (Table 4). The inclusion of the interaction between residential NOE availability and gender, age or city was not statistically significant (Table A4).

\subsection{NOE MVPA}

The higher residential NOE availability (i.e., having NOE in the $300 \mathrm{~m}$ buffer around the residence instead of not having it), the more NOE MVPA during weekdays. This was found both in the pooled analyses and when stratified by gender and by age (Tables 2, 3 and 5).

When stratifying by city (Table 4), having residential NOE availability was also statistically significantly associated with higher NOE MVPA for our Barcelona participants (both during weekdays and weekend days). Contrary, for our Kaunas sample, negative links were found during weekend days.

On weekdays, the inclusion of the interaction with city was statistically significant, while on weekend days interaction inclusion was statistically significant with age and city (Table A4).

\subsection{Sensitivity Analyses}

Sensitivity analyses showed consistent results (Tables A5-A9). However, the effect of residential NOE availability on contact with NOE disappeared when investigating $1 \mathrm{~km}$ buffer sizes (Table A9). Similarly, the effect of having NOE around the residence on NOE MVPA vanished to marginally statistically significant in the models for $150 \mathrm{~m}$ buffer size (Table A7). 
Table 2. Adjusted models for residential NOE availability at 300 m network buffer.

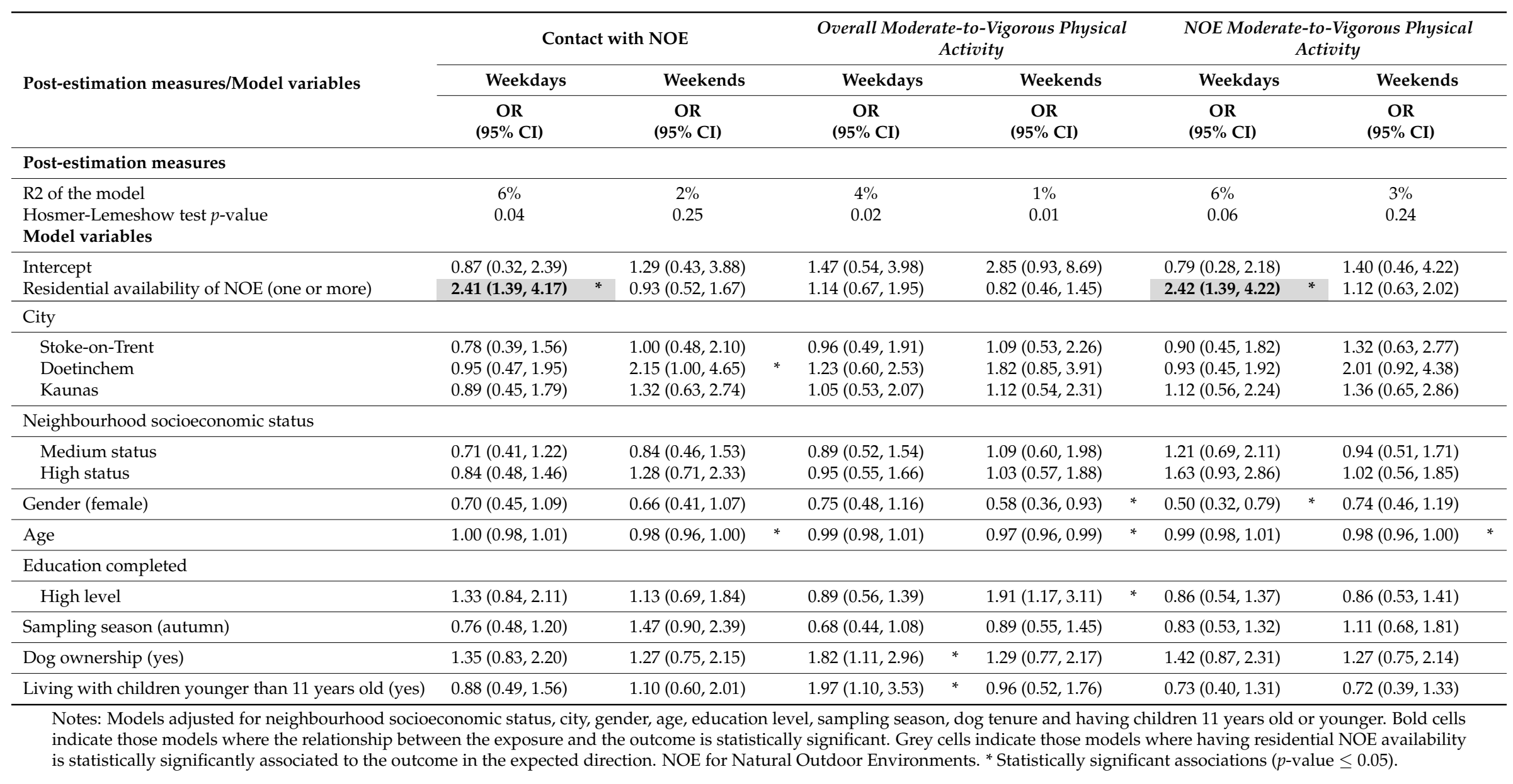


Table 3. Adjusted models for residential NOE availability at 300 m network buffer, stratified by age.

\begin{tabular}{|c|c|c|c|c|c|c|}
\hline \multirow[b]{2}{*}{ Outcomes } & \multicolumn{2}{|c|}{ Below Median Age } & \multicolumn{4}{|c|}{ Above Median Age } \\
\hline & $\begin{array}{l}\text { Estimate } \\
(95 \% \text { CI) }\end{array}$ & $p$-Value & & $\begin{array}{l}\text { Estimate } \\
(95 \% \text { CI) }\end{array}$ & $p$-Value & \\
\hline \multicolumn{7}{|l|}{ Contact with NOE } \\
\hline Weekdays & $2.28(1.01,5.12)$ & 0.05 & (1) & $3.02(1.32,6.89)$ & 0.01 & (7) \\
\hline Weekend days & $0.47(0.20,1.09)$ & 0.08 & (2) & $2.00(0.82,4.91)$ & 0.13 & (8) \\
\hline \multicolumn{7}{|c|}{ Overall moderate-to-vigorous physical activity } \\
\hline Weekdays & $1.18(0.54,2.59)$ & 0.68 & (3) & $1.09(0.51,2.32)$ & 0.83 & (9) \\
\hline Weekend days & $0.71(0.31,1.62)$ & 0.42 & (4) & $0.94(0.41,2.13)$ & 0.88 & (10) \\
\hline \multicolumn{7}{|c|}{ NOE moderate-to-vigorous physical activity } \\
\hline Weekdays & $3.05(1.28,7.27)$ & 0.01 & (5) & $2.31(1.07,5.02)$ & 0.03 & (11) \\
\hline Weekend days & $0.72(0.31,1.65)$ & 0.44 & (6) & $2.45(0.97,6.19)$ & 0.06 & (12) \\
\hline
\end{tabular}

Notes: Models adjusted for neighbourhood socioeconomic status, city, gender, education level, sampling season, dog tenure and having children 11 years old or younger. For below median age: (1) $\mathrm{R} 2=5 \%$, Hosmer-Lemeshow $p$-value test $=0.27$; $^{(2)} \mathrm{R} 2=3 \%$, Hosmer-Lemeshow $p$-value test $=0.02 ;{ }^{(3)} \mathrm{R} 2=6 \%$, Hosmer-Lemeshow $p$-value test $<0.01 ;{ }^{(4)} \mathrm{R} 2=3 \%$, Hosmer-Lemeshow $p$-value test $<0.01 ;{ }^{(5)} \mathrm{R} 2=12 \%$, Hosmer-Lemeshow $p$-value test $=0.60 ;{ }^{(6)} \mathrm{R} 2=3 \%$, Hosmer-Lemeshow $p$-value test $=0.50$. For above median age: ${ }^{(7)} \mathrm{R} 2=12 \%$, Hosmer-Lemeshow $p$-value test $=0.27 ;{ }^{(8)} \mathrm{R} 2=7 \%$, Hosmer-Lemeshow $p$-value test $=0.73 ;{ }^{(9)} \mathrm{R} 2=4 \%$, Hosmer-Lemeshow $p$-value test $=0.02 ;{ }^{(10)} \mathrm{R} 2=-1 \%$, Hosmer-Lemeshow $p$-value test $<0.01 ;{ }^{(11)} \mathrm{R} 2=6 \%$, Hosmer-Lemeshow $p$-value test $=0.57 ;{ }^{(12)} \mathrm{R} 2=7 \%$, Hosmer-Lemeshow $p$-value test $=0.55$. Bold cells indicate those models where the association is statistically significant. Grey cells indicate those models where having residential NOE availability is statistically significantly associated to the outcome in the expected direction. NOE for Natural Outdoor Environments. Statistically significant associations ( $p$-value $\leq 0.05)$. 
Table 4. Adjusted models for residential NOE availability at 300 m network buffer, stratified by city.

\begin{tabular}{|c|c|c|c|c|c|c|c|c|c|c|c|c|}
\hline \multirow{3}{*}{ Outcomes } & \multicolumn{2}{|c|}{ Barcelona } & & \multicolumn{2}{|c|}{ Stoke-on-Trent } & & \multicolumn{2}{|c|}{ Doetinchem } & & \multicolumn{2}{|c|}{ Kaunas } & \\
\hline & OR & \multirow{2}{*}{$p$-Value } & & OR & \multirow{2}{*}{$p$-Value } & & OR & \multirow{2}{*}{$p$-Value } & & OR & \multirow{2}{*}{$p$-Value } & \\
\hline & $(95 \% \mathrm{CI})$ & & & $(95 \% \mathrm{CI})$ & & & $(95 \% \mathrm{CI})$ & & & $(95 \% \mathrm{CI})$ & & \\
\hline \multicolumn{13}{|l|}{ Contact with NOE } \\
\hline Weekdays & $5.35(2.05,13.95)$ & $<0.01$ & (1) & $1.34(0.36,4.92)$ & 0.66 & (7) & $1.97(0.15,25.74)$ & 0.61 & (13) & $0.77(0.23,2.63)$ & 0.68 & (19) \\
\hline Weekend days & $0.95(0.35,2.58)$ & 0.92 & (2) & $2.05(0.50,8.39)$ & 0.32 & (8) & $1.26(0.09,17.72)$ & 0.87 & $(14)$ & $0.39(0.12,1.29)$ & 0.12 & $(20)$ \\
\hline \multicolumn{13}{|c|}{ Overall moderate-to-vigorous physical activity } \\
\hline Weekdays & $1.23(0.53,2.90)$ & 0.63 & (3) & $0.67(0.18,2.51)$ & 0.55 & (9) & $1.05(0.07,15.19)$ & 0.97 & (15) & $0.60(0.20,1.84)$ & 0.37 & (21) \\
\hline Weekend days & $0.85(0.33,2.17)$ & 0.73 & (4) & $3.81(0.88,16.44)$ & 0.07 & (10) & $0.52(0.03,7.97)$ & 0.64 & (16) & $0.18(0.05,0.66)$ & 0.01 & (22) \\
\hline \multicolumn{13}{|c|}{ NOE moderate-to-vigorous physical activity } \\
\hline Weekdays & $7.62(2.84,20.40)$ & $<0.01$ & (5) & $0.90(0.20,3.94)$ & 0.89 & (11) & $1.17(0.09,15.73)$ & 0.91 & (17) & $0.74(0.23,2.34)$ & 0.61 & (23) \\
\hline Weekend days & $3.71(1.23,11.21)$ & 0.02 & (6) & $2.29(0.54,9.67)$ & 0.26 & (12) & $1.36(0.09,19.35)$ & 0.82 & (18) & $0.19(0.05,0.68)$ & 0.01 & (24) \\
\hline
\end{tabular}

Notes: Models adjusted for neighbourhood socioeconomic status, gender, age, education level, sampling season, dog tenure and having children 11 years old or younger. Pooled analyses also include city as a covariate. McFadden's R2 range from $<0.01$ to 0.23 . Hosmer-Lemeshow test results range from Chi2 $=39.59(p$-value $<0.01)$ to Chi2 $=1.60(p$-value $=0.99)$. For Barcelona: ${ }^{(1)} \mathrm{R} 2=12 \%$, Hosmer-Lemeshow $p$-value test $=0.06$; ${ }^{(2)} \mathrm{R} 2=7 \%$, Hosmer-Lemeshow $p$-value test $=0.11 ;{ }^{(3)} \mathrm{R} 2=2 \%$, Hosmer-Lemeshow $p$-value test $=0.15$; ${ }^{(4)}$ : R2 $<1 \%$, Hosmer-Lemeshow $p$-value test $<0.01 ;{ }^{(5)} \mathrm{R} 2=21 \%$, Hosmer-Lemeshow $p$-value test $=0.31{ }^{(6)} \mathrm{R} 2=19 \%$, Hosmer-Lemeshow $p$-value test $=0.81$. For Stoke-on-Trent: ${ }^{(7)} \mathrm{R} 2=12 \%$, Hosmer-Lemeshow $p$-value test $=0.57 ;{ }^{(8)} \mathrm{R} 2=7 \%$, Hosmer-Lemeshow $p$-value test $=0.84 ;{ }^{(9)} \mathrm{R} 2=23 \%$, Hosmer-Lemeshow $p$-value test $<0.01 ;{ }^{(10)} \mathrm{R} 2=17 \%$, Hosmer-Lemeshow $p$-value test $<0.01 ;{ }^{(11)} \mathrm{R} 2=23 \%$, Hosmer-Lemeshow $p$-value test $=0.75 ;{ }^{(12)} \mathrm{R} 2=7 \%$, Hosmer-Lemeshow $p$-value test $=0.30$. For Doetinchem: $(13) \mathrm{R} 2=3 \%$, Hosmer-Lemeshow $p$-value test $=0.35 ;{ }^{(14)} \mathrm{R} 2=5 \%$, Hosmer-Lemeshow $p$-value test $=0.01 ;{ }^{(15)} \mathrm{R} 2=16 \%$, Hosmer-Lemeshow $p$-value test $<0.01 ;{ }^{(16)} \mathrm{R} 2=11 \%$, Hosmer-Lemeshow $p$-value test $<0.01$; ${ }^{(17)} \mathrm{R} 2=8 \%$, Hosmer-Lemeshow $p$-value test $<0.01 ;{ }^{(18)} \mathrm{R} 2=4 \%$, Hosmer-Lemeshow $p$-value test $=0.37$. For Kaunas, ${ }^{(19)} \mathrm{R} 2=19 \%$, Hosmer-Lemeshow $p$-value test $=0.05 ;{ }^{(20)} \mathrm{R} 2=3 \%$, Hosmer-Lemeshow $p$-value test $=0.66$; ${ }^{(21)} \mathrm{R} 2=7 \%$, Hosmer-Lemeshow $p$-value test $=0.36$; ${ }^{(22)} \mathrm{R} 2=13 \%$, Hosmer-Lemeshow $p$-value test $<0.01$; ${ }^{(23)} \mathrm{R} 2=9 \%$, Hosmer-Lemeshow $p$-value test $=0.99 ;{ }^{(24)} \mathrm{R} 2=10 \%$, Hosmer-Lemeshow $p$-value test $=0.93$. Bold cells indicate those models where the association is statistically significant. Grey cells indicate those models where having residential NOE availability is statistically significantly associated to the outcome in the expected direction. NOE for Natural Outdoor Environments. Statistically significant associations $(p$-value $\leq 0.05)$ 
Table 5. Adjusted models for residential NOE availability at 300 m network buffer, stratified by gender.

\begin{tabular}{|c|c|c|c|c|c|c|}
\hline \multirow[b]{2}{*}{ Outcomes } & \multicolumn{2}{|c|}{ Males } & \multicolumn{4}{|c|}{ Females } \\
\hline & $\begin{array}{l}\text { Estimate } \\
(95 \% \text { CI })\end{array}$ & $p$-Value & & $\begin{array}{l}\text { Estimate } \\
(95 \% \text { CI })\end{array}$ & $p$-Value & \\
\hline \multicolumn{7}{|l|}{ Contact with NOE } \\
\hline Weekdays & $1.83(0.84,3.97)$ & 0.13 & (1) & $3.70(1.55,8.79)$ & $<0.01$ & (7) \\
\hline Weekend days & $0.69(0.29,1.63)$ & 0.40 & (2) & $1.36(0.58,3.17)$ & 0.48 & $(8)$ \\
\hline \multicolumn{7}{|c|}{ Overall moderate-to-vigorous physical activity } \\
\hline Weekdays & $0.90(0.41,1.97)$ & 0.79 & (3) & $1.59(0.72,3.49)$ & 0.25 & (9) \\
\hline Weekend days & $0.83(0.35,1.96)$ & 0.68 & (4) & $0.71(0.31,1.63)$ & 0.42 & (10) \\
\hline \multicolumn{7}{|c|}{ NOE moderate-to-vigorous physical activity } \\
\hline Weekdays & $2.32(1.06,5.06)$ & 0.04 & (5) & $2.63(1.11,6.24)$ & 0.03 & (11) \\
\hline Weekend days & $2.10(0.89,4.98)$ & 0.09 & (6) & $0.55(0.22,1.36)$ & 0.19 & (12) \\
\hline
\end{tabular}

Notes: Models adjusted for neighbourhood socioeconomic status, city, age, education level, sampling season, dog tenure and having children 11 years old or younger. For males: ${ }^{(1)} \mathrm{R} 2=5 \%$, Hosmer-Lemeshow $p$-value test $<0.01 ;{ }^{(2)} \mathrm{R} 2=5 \%$, Hosmer-Lemeshow $p$-value test $=0.37 ;{ }^{(3)} \mathrm{R} 2=6 \%$, Hosmer-Lemeshow $p$-value test $<0.01$; (4) $\mathrm{R} 2=8 \%$, Hosmer-Lemeshow $p$-value test $<0.01 ;{ }^{(5)} \mathrm{R} 2=5 \%$, Hosmer-Lemeshow $p$-value test $=0.61 ;{ }^{(6)} \mathrm{R} 2=5 \%$, Hosmer-Lemeshow $p$-value test $=0.37$. For females: ${ }^{(7)} \mathrm{R} 2=6 \%$, Hosmer-Lemeshow $p$-value test $=0.68$; (8) $\mathrm{R} 2=9 \%$, Hosmer-Lemeshow $p$-value test $=0.57{ }^{\left({ }^{(9)}\right.} \mathrm{R} 2=4 \%$, Hosmer-Lemeshow $p$-value test $=0.01 ;{ }^{(10)} \mathrm{R} 2=3 \%$, Hosmer-Lemeshow $p$-value test $=0.02 ;{ }^{(11)} \mathrm{R} 2=11 \%$, Hosmer-Lemeshow $p$-value test $\left.=0.97 ;{ }^{12}\right) \mathrm{R} 2=9 \%$, Hosmer-Lemeshow $p$-value test $=0.57$. Bold cells indicate those models where the association is statistically significant. Grey cells indicate those models where having residential NOE availability is statistically significantly associated to the outcome in the expected direction. NOE for Natural Outdoor Environments. Statistically significant associations $(p$-value $\leq 0.05)$

\section{Discussion}

We found that residential NOE availability was positively linked to NOE contact, when considering most of the week (i.e., weekdays). No associations were found between residential NOE availability and overall PA. Meanwhile, we found that the higher residential NOE availability, the more NOE PA, especially four our Barcelona participants.

\subsection{Contact with NOE}

Our data showed that having residential NOE availability was associated with higher NOE contact during most of the week (i.e., weekdays). This is in line with previous studies $[19,21-23,57]$. Our results show that this relationship is consistent using either objective or subjective measurement tools and across countries, as most of the previous studies have used questionnaires and have focused on northern countries. Our findings also indicate that people do not compensate a lack of NOE close to residence with fewer, longer visits to NOE that are further from the home [19].

\subsection{Overall $M V P A$}

We found no associations between residential NOE availability and overall MVPA. These results add to the current mixed evidence on the links between green spaces and objectively measured PA [29]. Sallis et al. [30] found that the higher number of parks at $500 \mathrm{~m}$ buffer around residence, the more MVPA in 14 cities from 10 different countries from around the globe. However, Sallis et al. adjusted their model for NOE availability and also by residential density, public transport density and pedestrian-accessible street intersections, which we were not able to do. Contrary, Carlson et al. [56] did not report links between number of parks and private recreation facilities within $500 \mathrm{~m}$ of residence and objectively measured MVPA (assessed with ActiGraph accelerometers) in different U.S. cities. In their study, Carlson et al. adjusted their models for walkability, aesthetics, walking facilities, social support, self-efficacy, barriers and several potential interactions between the previous factors. Interestingly, they found that MVPA was influenced by social support, self-efficacy and interactions between walkability and social support and between barriers and aesthetics. Similarly, no relationships 
were found between MVPA and green spaces indicators by Saelens et al. [59], but they found that higher MVPA was linked to commercial locations.

Taking into account our finding and the previous evidence together, there is no suggestion for clear patterns for the links between residential NOE availability and overall PA between cities, population groups, or GIS-measured NOE indicators. Also, as noted by Bancroft et al. neighbourhood characteristics related with access to NOE (e.g., street configuration, accessibility, or crime) and NOE characteristics (e.g., aesthetics, safety, amenities, facilities, or perceived quality) could modify the association between overall PA and NOE, or even be better predictors of residents' PA levels [29].

\subsection{NOE MVPA}

Our findings of residential NOE availability being tied to NOE MVPA during most of the week (i.e., weekdays) in pooled analyses and during the whole week (i.e., weekdays and weekends) for our Barcelona participants, contradict previous studies that did not find a link $[37,43,60]$. All the previous studies characterized natural environment availability using indicators of access to large NOE. Moreover, all of them were exploring the relationships in northern countries (i.e., countries between $50^{\circ}$ and $60^{\circ}$ of latitude). Thus their results are consistent with our lack of associations between access to large NOE in northern European cities (i.e., our Stoke-on-Trent, Kaunas and Doetinchem samples). Our results suggest that NOE PA is positively related with residential NOE availability, especially in those areas where NOE availability is low, as is the case of Barcelona, or the previously studied Odense in Denmark [43]. Ou et al. reported a positive link between PA and proximity to resident-preferred park, but no association with proximity to all parks or parks with sports/walking facilities [47]. We hypothesize that in areas with high NOE availability, greater choice results in more differences between proximity to resident-preferred NOE and proximity to nearest NOE. Meanwhile, in environments with low NOE availability, it is more likely that the nearest NOE will be the "preferred" park for residents.

\subsection{Strengths and Limitations}

Our study is the first to use objective and standardized measures of NOE availability and objective measures of NOE contact and PA in four different European cities. This is also one of the first studies to evaluate objectively determined PA location. Consequently, this manuscript presents new findings that would be more easily translated into policies than findings from subjective measures.

Limitations of the study are as follows. First, causality cannot be inferred as our study has a nested cross-sectional design. Second, this was not a completely random sample. Participants were more physically active than the original sample from which they were recruited, so it seems that there was some self-selection bias. Consequently, our sample is not representative (especially not at city level). Third, there is the potential for measurement bias, as our PA measurement tool (CalFit) is less sensitive to certain activities that do not involve much vertical movement, such as cycling. This could be especially important for cities with a high percentage of cyclists like Doetinchem. Also, our NOE assessment (for residential availability, contact and NOE MVPA) was based on the mere presence, but we were not able to include real access (e.g., access points like doors) or quality indicators (e.g., safety). Moreover, the MVPA threshold we used (i.e., $\geq 3$ METs) was not relative to population characteristics what, for example, could lead to the inclusion of light physical activity in our MVPA definition for those participants who were very fit. Fourth, our sample was not big enough to stratify by gender, age and city simultaneously, which restricted our capacity to identify their potential modifying effects. Finally, we were not able to collect enough information to study the role of the workplaces or commuting routes on people's NOE contact and PA, despite some emerging evidence of their importance [61].

Future studies should involve different cities to provide a range of cultural contexts, with sufficiently large samples to allow stratification by gender, age, and city. Information and comparison on different NOE typologies (e.g., agricultural land compared with urban parks), quality of NOE, on 
NOE around workplaces and on contact with and MVPA performed close to residence would also be a valuable addition.

\section{Conclusions}

Our study provides evidence that residential availability of natural outdoor environments is associated with more time spent in natural outdoor environments, but is not linked to overall duration of physical activity. Relationships between residential availability of natural outdoor environments and physical activity in natural outdoor environments were observed for our Barcelona sample, participants that live in a city with low availability of natural outdoor environments, but not for the other city samples.

Policy makers should be cautious on using residential provision of natural outdoor environments to promote physical activity. Aside from physical activity, other health promoting aspects from the provision of natural outdoor environments should be explored.

Acknowledgments: This study was funded from the European Community's Seventh Framework Programme (FP/2007-2013) under grant agreement No: 282996 (ENV.2011.1.2.3-2). Margarita Triguero-Mas is funded by a pre-doctoral grant from the Catalan Government (AGAUR FI-DGR-2013).

Author Contributions: Margarita Triguero-Mas participated in the conception, design and planning of the study, performed literature revision, data analysis, interpretation of the results and manuscript writing. David Donaire-Gonzalez contributed in the conception, design, and production of outcome measures and data analysis of the manuscript. Edmund Seto participated in the conception, design and planning of the study, developed CalFit measurement application and technical assistance, and contributed to the revision of the manuscript. Antònia Valentín contributed in the geocoding process, contributed in the production of outcome measures, and contributed to manuscript writing. Graham Smith contributed in design of the study, the geocoding process, in the production of exposure measures and revised the manuscript critically. DMar guided statistical analysis and contributed in manuscript writing. Glòria Carrasco-Turigas, David Martínez, Daniel Masterson, Magdalena van den Berg, Albert Ambròs, Tania Martínez-Íñiguez, Gemma Hurst, Naomi Ellis, Tomas Grazulevicius, Martin Voorsmit, Eddy Clasquin collected data and revised the manuscript. Audrius Dedele, Marta Cirach and Wim Swart contributed in the geocoding process, in the production of exposure measures and contributed in manuscript writing. Judith Cirac-Claveras contributed in the data analysis and revised the manuscript critically. Wanda Wendel-Vos contributed to the revision of the manuscript. Jolanda Maas, Michael Jerret, Regina Gražulevičienè, Hanneke Kruize contributed in the conception of the study and in the revision of the manuscript. Christopher J. Gidlow participated in the conception of the study, interpretation of the results and manuscript writing. Mark J. Nieuwenhuijsen participated in the conception, design and planning of the study, supervised the data analysis, contributed in the interpretation of the results and in the revision of the manuscript. All authors saw and approved the final version of the manuscript. No financial disclosures were reported by the authors of this paper.

Conflicts of Interest: The authors declare no conflict of interest. The founding sources had no role in the design of the study; in the collection, analyses, or interpretation of data; in the writing of the manuscript, and in the decision to publish the results.

\section{Appendix A}

Table A1. Sampling strategy and participation details.

\begin{tabular}{lcccc}
\hline City & Invited $\boldsymbol{n}$ & $\begin{array}{c}\text { Willing to Participate } \boldsymbol{n} \\
\text { (\% from the Invited Ones) }\end{array}$ & Participated $\boldsymbol{n}$ & $\begin{array}{c}\text { Finally Included } \\
\text { in the Analyses }\end{array}$ \\
\hline Barcelona & 1044 & $379(37 \%)$ & 109 & 107 \\
Stoke-on-Trent & & $164(17 \%)$ & 99 & 92 \\
$\quad$ From the original sample & 1044 & $107(2.22 \%)$ & 49 & 45 \\
$\quad$ Further approaches & 4814 & $224(26 \%)$ & 50 & 47 \\
Doetinchem & 861 & $280(28 \%)$ & 111 & 105 \\
Kaunas & 997 & 112 & 104 \\
\hline
\end{tabular}

\section{Appendix A.1. CalFit Data Treatment}

We downloaded CalFit data, including both accelerometer and location data from the smartphones and processed data in three steps. 
(1) CalFit-recorded location data (including GPS and, when GPS data were not available, wireless network triangulation data) were converted into a Geographic Information Systems (GIS) data layer. We then attached the street network maps, and participant geocoded home and work addresses to the location data layer. After this, we resampled to $10 \mathrm{~s}$ to reduce the measurement error in the geolocation. Then we scanned the data sequentially looking for clusters of points based on the angular variability of its trajectory. This process identifies only the clearest clusters. Then, we made a spatial and temporal query around each point being part of a cluster to identify also the temporary closer points that are also spatially closer (i.e., points under the space and time threshold of $150 \mathrm{~m}$ and $30 \mathrm{~min}$ ). The rest of points not being part of a cluster were considered trips. Finally we used the geocoded home and work points to identify the clusters belonging to these locations. The other clusters were considered others places and we calculated the centroid of each of them. The trips, the centroids and the geocoded home and work location points were the data used to continue with the analyses. The next step was to add information from Urban Atlas 2006 and Top10 NL and to develop the indicator of the presence/absence of green spaces within a $50 \mathrm{~m}$ circular buffer for each location point. Those location points identified as home or work were considered non-exposed to green spaces. Finally, we resampled to one-minute assigning the mode of all the calculated indicators. This resampling was done because one-minute was the minimum meaningful physical activity information that our measurement instruments could provide.

(2) CalFit-recorded accelerometer was used to get two g-forces (vertical and horizontal). After this, we converted the vertical force recorded in g-force into counts using a linear regression, and these counts into METs using the equation of Freedson et al. [62], as CalFit METs $=1.2907087+$ $(0.4141791 \times \mathrm{VT} \mathrm{g} / \mathrm{min})$ [50]. We then defined time not wearing the CalFit as those periods of time of at least 40 consecutive minutes below $0.34 \mathrm{~g}$ in the vertical axis. These non-wear were excluded from analyses. We then classified those minutes with a MVPA intensity ( $\geq 3$ METs).

(3) We excluded those days that were non-study days (e.g., delivery and collection days) and classified the remainder as weekdays or weekend days. We then applied the criteria of three days with at least $10 \mathrm{~h}$ as valid assessment for physical activity during weekdays and, similarly, applied two days with at least $10 \mathrm{~h}$ during weekend days [51,52]. Those participants not fulfilling the weekdays criteria were excluded from the weekdays analyses, while those participants not fulfilling the weekend days criteria were excluded from the weekend days analyses. This led to a total sample for this study of 350 participants on weekdays and 308 on weekend days (408 participants with either weekdays or weekend days data). 
Table A2. Comparison of sample characteristics between the different cities. Results of Chi2, ANOVA, and posthoc Tukey, and Bonferroni tests.

\begin{tabular}{|c|c|c|c|c|c|c|c|c|}
\hline \multirow{2}{*}{ Characteristics } & \multicolumn{2}{|c|}{ Overall } & \multirow{2}{*}{$\frac{\text { BCN/SoT }}{p \text {-Value }}$} & \multirow{2}{*}{$\frac{\text { BCN/Doe }}{p \text {-Value }}$} & \multirow{2}{*}{$\frac{\text { BCN/Kau }}{p \text {-Value }}$} & \multirow{2}{*}{$\begin{array}{l}\text { SoT/Doe } \\
p \text {-Value }\end{array}$} & \multirow{2}{*}{$\begin{array}{c}\text { SoT/Kau } \\
p \text {-Value }\end{array}$} & \multirow{2}{*}{$\begin{array}{c}\text { Doe/Kau } \\
p \text {-Value }\end{array}$} \\
\hline & Chi2 & $p$-Value & & & & & & \\
\hline \multicolumn{9}{|l|}{ Sociodemographic characteristics } \\
\hline Gender & 2.94 & 0.40 & - & - & - & - & - & - \\
\hline Age & - & $<0.01$ & $0.05 \ddagger$ & $<0.01^{¥}$ & $<0.01^{\mathrm{d}}$ & $<0.01^{¥}$ & 0.23 & $0.01^{¥}$ \\
\hline Living with children $<11$ years old & 6.15 & 0.10 & - & - & - & - & - & - \\
\hline Dog ownership & 38.85 & $<0.01$ & 0.51 & 1.00 & $<0.01^{\text {a }}$ & 0.49 & $<0.01^{a}$ & $<0.01^{\text {a }}$ \\
\hline Highest education & 19.97 & $<0.01$ & 1.00 & 1.00 & $0.01^{\alpha}$ & 1.00 & $<0.01^{a}$ & $<0.01^{\text {a }}$ \\
\hline Neighbourhood SES & 11.47 & 0.07 & - & - & - & - & - & - \\
\hline Season & 13.07 & $<0.01$ & 0.09 & $<0.01^{¥}$ & $0.03 \not \alpha$ & 1.00 & 1.00 & 1.00 \\
\hline \multicolumn{9}{|l|}{$\begin{array}{l}\text { Residential availability of natural } \\
\text { outdoor environments }\end{array}$} \\
\hline $\begin{array}{l}\text { Presence/absence of green spaces at } 300 \\
m \text { network buffer }\end{array}$ & 76.71 & $<0.01$ & $<0.01 \ddagger$ & $<0.01^{¥}$ & $<0.01^{a}$ & $<0.01 ¥$ & 1.00 & $<0.01 ¥$ \\
\hline \multicolumn{9}{|l|}{ Weekdays } \\
\hline Contact with NOE & - & $<0.01$ & 0.82 & $<0.01^{¥}$ & 0.06 & $<0.01^{¥}$ & 0.47 & $<0.01^{¥}$ \\
\hline $\begin{array}{l}\text { Overall moderate-to-vigorous physical } \\
\text { activity }\end{array}$ & - & $<0.01$ & $<0.01^{\dagger}$ & $0.04^{+}$ & $<0.01^{\dagger}$ & 0.71 & 1.00 & 0.80 \\
\hline $\begin{array}{l}\text { NOE moderate-to-vigorous physical } \\
\text { activity }\end{array}$ & - & $<0.01$ & 0.99 & $<0.01^{¥}$ & 0.50 & $<0.01 ¥$ & 0.78 & $<0.01^{¥}$ \\
\hline \multicolumn{9}{|l|}{ Weekends } \\
\hline Contact with NOE & - & $<0.01$ & 0.26 & $<0.01^{¥}$ & 0.83 & $<0.01^{¥}$ & 0.76 & $<0.01^{¥}$ \\
\hline $\begin{array}{l}\text { Overall moderate-to-vigorous physical } \\
\text { activity }\end{array}$ & - & 0.01 & $0.01^{+}$ & 0.97 & 0.29 & $0.04^{¥}$ & 0.50 & 0.57 \\
\hline $\begin{array}{l}\text { NOE moderate-to-vigorous physical } \\
\text { activity }\end{array}$ & - & $<0.01$ & 0.96 & $<0.01 ¥$ & 1.00 & $<0.01 ¥$ & 0.93 & $<0.01 ¥$ \\
\hline
\end{tabular}

Notes: Grey cells for those statistically significant tests. BCN for Barcelona, SoT for Stoke-on-Trent, Doe for Doetinchem and Kau for Kaunas. For contact with NOE, overall moderate-to-vigorous physical activity, and NOE moderate-to-vigorous physical activity (including both during weekday and weekends), the table is reporting the original data without categorisation. ${ }^{\ddagger}$ Indicate those variables with higher values in Stoke-on-Trent. ${ }^{\dagger}$ Indicate those variables with higher values in Barcelona. ${ }^{¥}$ Indicate those variables with higher values in Doetinchem. ${ }^{\not}$ Indicate those variables with higher values in Kaunas. NOE for Natural Outdoor Environments.

Table A3. Comparison of outcomes between weekdays and weekends. T-student tests results.

\begin{tabular}{lccccc}
\hline Outcomes & $\begin{array}{c}\text { Pooled } \\
p \text {-Value }\end{array}$ & $\begin{array}{c}\text { Barcelona } \\
p \text {-Value }\end{array}$ & $\begin{array}{c}\text { Stoke-on-Trent } \\
p \text {-Value }\end{array}$ & $\begin{array}{c}\text { Doetinchem } \\
p \text {-Value }\end{array}$ & $\begin{array}{c}\text { Kaunas } \\
p \text {-Value }\end{array}$ \\
\hline $\begin{array}{l}\text { Contact with NOE } \\
\begin{array}{l}\text { Overall moderate-to-vigorous } \\
\text { physical activity }\end{array}\end{array}$ & $<0.01$ & $<0.01$ & 0.12 & 0.91 & 0.23 \\
$\begin{array}{l}\text { NOE moderate-to-vigorous } \\
\text { physical activity }\end{array}$ & $<0.01$ & $<0.01$ & 0.02 & 0.48 & 0.14 \\
\hline
\end{tabular}

Notes: For contact with NOE, overall moderate-to-vigorous physical activity, and NOE moderate-to-vigorous physical activity (including both during weekday and weekends), the table is reporting the original data without categorisation. Bold cells indicate that weekend values are higher than weekdays. Italics indicate that weekdays values are higher than weekends. NOE for Natural Outdoor Environments. 
Table A4. Estimates of interaction terms (with $95 \% \mathrm{CI}$ ) and $p$-value of the likelihood ratio test comparing the model with and without the interaction term between residential NOE availability (defined as presence/absence of green spaces at $300 \mathrm{~m}$ network buffer) and gender, age, city.

\begin{tabular}{|c|c|c|c|c|c|c|c|c|}
\hline \multirow[b]{2}{*}{ Outcomes } & \multicolumn{2}{|l|}{ Gender } & \multicolumn{2}{|l|}{ Age } & \multicolumn{4}{|c|}{ City } \\
\hline & $\begin{array}{c}\text { Female } x \text { residential NOE } \\
\text { availability-Estimate } \\
(95 \% \mathrm{CI})\end{array}$ & $\begin{array}{c}p \text {-value of chi-2 } \\
\text { test }\end{array}$ & $\begin{array}{c}\text { Age above median age } x \\
\text { residential NOE } \\
\text { availability-Estimate } \\
(95 \% \mathrm{CI})\end{array}$ & $\begin{array}{c}p \text {-value of chi-2 } \\
\text { test }\end{array}$ & $\begin{array}{c}\text { Stoke-on-Trent } x \\
\text { residential NOE } \\
\text { availability-Estimate } \\
(95 \% \mathrm{CI})\end{array}$ & $\begin{array}{l}\text { Doetinchem } x \\
\text { residential NOE } \\
\text { availability }\end{array}$ & $\begin{array}{c}\text { Kaunas } x \text { residential NOE } \\
\text { availability-Estimate } \\
(95 \% \mathrm{CI})\end{array}$ & $\begin{array}{c}p \text {-value of chi-2 } \\
\text { test }\end{array}$ \\
\hline \multicolumn{9}{|l|}{ Contact with NOE } \\
\hline Weekdays & $0.81(0.48,1.38)$ & 0.30 & $0.77(0.44,1.33)$ & 0.51 & $0.51(0.21,1.22)$ & $0.71(0.32,1.62)$ & $0.58(0.24,1.40)$ & 0.38 \\
\hline Weekend days & $0.82(0.46,1.46)$ & 0.20 & $0.74(0.40,1.34)$ & 0.12 & $1.06(0.42,2.66)$ & $2.03(0.86,4.83)$ & $0.92(0.36,2.35)$ & 0.28 \\
\hline \multicolumn{9}{|c|}{ Overall moderate-to-vigorous physical activity } \\
\hline Weekdays & $0.93(0.55,1.58)$ & 0.15 & $0.69(0.40,1.19)$ & 0.55 & $0.83(0.35,1.96)$ & $1.12(0.50,2.52)$ & $0.86(0.36,2.07)$ & 0.89 \\
\hline Weekend days & $0.56(0.32,1.01)$ & 0.88 & $0.94(0.52,1.71)$ & 0.36 & $1.46(0.58,3.68)$ & $1.79(0.75,4.25)$ & $0.82(0.32,2.07)$ & 0.06 \\
\hline \multicolumn{9}{|c|}{ NOE moderate-to-vigorous physical activity } \\
\hline Weekdays & $0.57(0.33,0.97)$ & 0.42 & $0.87(0.50,1.51)$ & 0.64 & $0.45(0.19,1.10)$ & $0.56(0.25,1.29)$ & $0.52(0.21,1.26)$ & 0.03 \\
\hline Weekend days & $0.66(0.37,1.18)$ & 0.52 & $1.10(0.60,1.99)$ & 0.02 & $0.98(0.40,2.42)$ & $1.37(0.58,3.21)$ & $0.54(0.21,1.40)$ & 0.01 \\
\hline
\end{tabular}

Table A5. Sensitivity models. Adjusted models for residential NOE availability defined as presence/ absence of green spaces at $300 \mathrm{~m}$ network buffer excluding Doetinchem.

\begin{tabular}{lcc}
\hline \multirow{2}{*}{ Outcomes } & \multicolumn{2}{c}{ Total } \\
\cline { 2 - 3 } & & Estimate $\mathbf{( 9 5 \%} \mathbf{C I})$ \\
\hline Contact with NOE & $\mathbf{2 . 2 8}(\mathbf{1 . 2 9 , 4 . 0 4 )}$ & $<$-Value \\
\hline Weekdays & $0.88(0.48,1.62)$ & 0.68 \\
Weekend days & & 0.85 \\
\hline Overall moderate-to-vigorous physical activity & $1.06(0.61,1.84)$ & 0.52 \\
\hline Weekdays & $0.82(0.45,1.49)$ & $<0.01$ \\
Weekend days & & 0.77 \\
\hline NOE moderate-to-vigorous physical activity & $\mathbf{2 . 4 2 ( 1 . 3 5 , 4 . 3 2 )}$ \\
\hline Weekdays & $1.10(0.59,2.03)$ & \\
Weekend days &
\end{tabular}

Notes: Models adjusted for neighbourhood socioeconomic status, city, gender, age, education level, sampling season, dog tenure and having children 11 years old or younger. Bold cells indicate those models where the association is statistically significant. Grey cells indicate those models where having residential NOE availability is statistically significantly associated to the outcome in the expected direction. NOE for Natural Outdoor Environments. * Statistically significant associations $(p$-value $\leq 0.05)$ 
Table A6. Sensitivity models. Adjusted models for residential NOE availability defined as presence/ absence of green spaces at $300 \mathrm{~m}$ Euclidean buffer.

\begin{tabular}{|c|c|c|}
\hline \multirow{2}{*}{ Outcomes } & \multicolumn{2}{|c|}{ Total } \\
\hline & Estimate $(95 \% \mathrm{CI})$ & $p$-Value \\
\hline \multicolumn{3}{|l|}{ Contact with NOE } \\
\hline Weekdays & $2.62(1.26,5.44)$ & 0.01 \\
\hline Weekend days & $1.30(0.60,2.83)$ & 0.51 \\
\hline \multicolumn{3}{|c|}{ Overall moderate-to-vigorous physical activity } \\
\hline Weekdays & $1.35(0.66,2.76)$ & 0.41 \\
\hline Weekend days & $1.07(0.50,2.30)$ & 0.86 \\
\hline \multicolumn{3}{|c|}{ NOE moderate-to-vigorous physical activity } \\
\hline Weekdays & $4.19(1.91,9.18)$ & $<0.01$ \\
\hline Weekend days & $1.69(0.75,3.80)$ & 0.20 \\
\hline
\end{tabular}

Notes: Models adjusted for neighbourhood socioeconomic status, city, gender, age, education level, sampling season, dog tenure and having children 11 years old or younger. Bold cells indicate those models where the association is statistically significant. Grey cells indicate those models where having residential NOE availability is statistically significantly associated to the outcome in the expected direction. NOE for Natural Outdoor Environments. * Statistically significant associations ( $p$-value $\leq 0.05$ ).

Table A7. Sensitivity models. Adjusted models for residential NOE availability defined as presence/ absence of green spaces at $150 \mathrm{~m}$ Euclidean buffer.

\begin{tabular}{lcc}
\hline \multirow{2}{*}{ Outcomes } & \multicolumn{2}{c}{ Total } \\
\cline { 2 - 3 } & Estimate $\mathbf{9 5 \%} \mathrm{CI})$ & $p$-Value \\
\hline Contact with NOE & & \\
\hline Weekdays & $\mathbf{1 . 8 2}(\mathbf{1 . 0 6}, \mathbf{3 . 1 2})$ & $\mathbf{0 . 0 3}$ \\
Weekend days & $1.61(0.90,2.88)$ & 0.11 \\
\hline Overall moderate-to-vigorous physical activity & & \\
\hline Weekdays & $0.69(0.40,1.18)$ & 0.18 \\
Weekend days & $0.66(0.37,1.17)$ & 0.15 \\
\hline NOE moderate-to-vigorous physical activity & & \\
\hline Weekdays & $1.62(0.94,2.79)$ & 0.08 \\
Weekend days & $1.37(0.77,2.45)$ & 0.29 \\
\hline
\end{tabular}

Notes: Models adjusted for neighbourhood socioeconomic status, city, gender, age, education level, sampling season, dog tenure and having children 11 years old or younger. Bold cells indicate those models where the association is statistically significant. Grey cells indicate those models where having residential NOE availability is statistically significantly associated to the outcome in the expected direction. NOE for Natural Outdoor Environments. * Statistically significant associations ( $p$-value $\leq 0.05$ ).

Table A8. Sensitivity models. Adjusted models for residential NOE availability defined as presence/ absence of green spaces at $500 \mathrm{~m}$ network buffer.

\begin{tabular}{lcc}
\hline \multirow{2}{*}{ Outcomes } & \multicolumn{2}{c}{ Total } \\
\cline { 2 - 3 } & Estimate $\mathbf{( 9 5 \%}$ CI) & $p$-Value \\
\hline Contact with NOE & $\mathbf{2 . 2 5}(\mathbf{1 . 1 4}, \mathbf{4 . 4 2})$ & $\mathbf{0 . 0 2}$ \\
\hline Weekdays & $1.27(0.62,2.58)$ & 0.52 \\
Weekend days & & \\
\hline Overall moderate-to-vigorous physical activity & $0.99(0.51,1.90)$ & 0.97 \\
\hline Weekdays & $0.78(0.39,1.57)$ & 0.49 \\
$\quad$ Weekend days & & \\
\hline NOE moderate-to-vigorous physical activity & $\mathbf{2 . 4 1}(\mathbf{1 . 2 1}, \mathbf{4 . 7 9 )}$ & $\mathbf{0 . 0 1}$ \\
\hline Weekdays & $1.20(0.58,2.47)$ & 0.62 \\
\hline Weekend days
\end{tabular}

Notes: Models adjusted for neighbourhood socioeconomic status, city, gender, age, education level, sampling season, dog tenure and having children 11 years old or younger. Bold cells indicate those models where the association is statistically significant. Grey cells indicate those models where having residential NOE availability is statistically significantly associated to the outcome in the expected direction. NOE for Natural Outdoor Environments. * Statistically significant associations ( $p$-value $\leq 0.05)$. 
Table A9. Sensitivity models. Adjusted models for residential NOE availability defined as presence of few / a lot of green spaces at $1000 \mathrm{~m}$ network buffer (with four green spaces as cut-off point).

\begin{tabular}{lcc}
\hline \multirow{2}{*}{ Outcomes } & \multicolumn{2}{c}{ Total } \\
\cline { 2 - 3 } & Estimate $\mathbf{( 9 5 \%}$ CI) & p-Value \\
\hline Contact with NOE & & \\
\hline Weekdays & $1.39(0.75,2.59)$ & 0.30 \\
Weekend days & $1.25(0.61,2.54)$ & 0.54 \\
\hline Overall moderate-to-vigorous physical activity & & \\
\hline Weekdays & $0.75(0.40,1.39)$ & 0.36 \\
Weekend days & $1.00(0.50,2.00)$ & 0.99 \\
\hline NOE moderate-to-vigorous physical activity & & \\
\hline Weekdays & $\mathbf{1 . 9 4}(\mathbf{1 . 0 2}, \mathbf{3 . 7 0})$ & $\mathbf{0 . 0 4}$ \\
$\quad$ Weekend days & $1.49(0.71,3.13)$ & 0.29 \\
\hline
\end{tabular}

Notes: Models adjusted for neighbourhood socioeconomic status, city, gender, age, education level, sampling season, dog tenure and having children 11 years old or younger. Bold cells indicate those models where the association is statistically significant. Grey cells indicate those models where having residential NOE availability is statistically significantly associated to the outcome in the expected direction. NOE for Natural Outdoor Environments. * Statistically significant associations ( $p$-value $\leq 0.05)$.

\section{References}

1. Hunter, R.F.; Christian, H.; Veitch, J.; Astell-Burt, T.; Hipp, J.A.; Schipperijn, J. The impact of interventions to promote physical activity in urban green space: A systematic review and recommendations for future research. Soc. Sci. Med. 2015, 124, 246-256. [CrossRef] [PubMed]

2. Almanza, E.; Jerrett, M.; Dunton, G.; Seto, E.; Ann Pentz, M. A study of community design, greenness, and physical activity in children using satellite, GPS and accelerometer data. Health Place 2012, 18, 46-54. [CrossRef] [PubMed]

3. Mytton, O.T.; Townsend, N.; Rutter, H.; Foster, C. Green space and physical activity: An observational study using Health Survey for England data. Health Place 2012, 18, 1034-1041. [CrossRef] [PubMed]

4. European Commission. Towards a Local Sustainability Profile. European Common Indicators; Methodology Sheets; European Commission: Luxembourg, Luxembourg, 2001.

5. Public Health Office Copenhagen. Sunde Københavnere i Alle Aldre-Københavns Kommunes Sundhedspolitik 2006-2010 (Healthy Copenhageners in All Ages-Healthy Policy of the Municipality of Copenhagen for 2006-2010 (Internet). 2006. Available online: http://www.kk.dk/sites/default/files/ edoc_old_format/Sundheds-\%20og\%20Omsorgsudvalget/21-09-2006\%2014.00.00/Dagsorden/15-092006\%2014.12.08/Bilag\%201\%20Andet\%20udkast\%20til\%20Sundhedspolitikken.PDF (accessed on 17 January 2016).

6. Van den Bosch, M.A.; Mudu, P.; Uscila, V.; Barrdahl, M.; Kulinkina, A.; Staatsen, B.; Swart, W.; Kruize, H.; Zurlyte, I.; Egorov, A.I. Development of an urban green space indicator and the public health rationale. Scand. J. Public Health 2016, 442, 159-167. [CrossRef] [PubMed]

7. Dadvand, P.; Sunyer, J.; Basagaña, X.; Ballester, F.; Lertxundi, A.; Fernández-Somoano, A.; Estarlich, M.; García-Esteban, R.; Mendez, M.A.; Nieuwenhuijsen, M.J. Surrounding Greenness and Pregnancy Outcomes in Four Spanish Birth Cohorts. Environ. Health Perspect. 2012, 120, 1481-1487. [CrossRef] [PubMed]

8. McEachan, R.R.C.; Prady, S.L.; Smith, G.; Fairley, L.; Cabieses, B.; Gidlow, C.; Wright, J.; Dadvand, P.; van Gent, D.; Nieuwenhuijsen, M.J. The association between green space and depressive symptoms in pregnant women: Moderating roles of socioeconomic status and physical activity. J. Epidemiol. Community Health 2015, 70, 253-259. [CrossRef] [PubMed]

9. Triguero-Mas, M.; Dadvand, P.; Cirach, M.; Martínez, D.; Medina, A.; Mompart, A.; Basagaña, X.; Gražulevičienè, R.; Nieuwenhuijsen, M.J. Natural outdoor environments and mental and physical health: Relationships and mechanisms. Environ. Int. 2015, 77, 35-41. [CrossRef] [PubMed]

10. Tamosiunas, A.; Grazuleviciene, R.; Luksiene, D.; Dedele, A.; Reklaitiene, R.; Baceviciene, M.; Vencloviene, J.; Bernotiene, G.; Radisauskas, R.; Malinauskiene, V. Accessibility and use of urban green spaces, and cardiovascular health: Findings from a Kaunas cohort study. Environ. Health 2014, 13, 20. [CrossRef] [PubMed] 
11. Astell-Burt, T.; Mitchell, R.; Hartig, T. The association between green space and mental health varies across the lifecourse. A longitudinal study. J. Epidemiol. Community Health 2014, 68, 578-583. [CrossRef] [PubMed]

12. Dadvand, P.; Wright, J.; Martinez, D.; Basagaña, X.; McEachan, R.R.C.; Cirach, M.; Gidlow, C.J.; de Hoogh, K.; Gražulevičienė, R.; Nieuwenhuijsen, M.J. Inequality, green spaces, and pregnant women: Roles of ethnicity and individual and neighbourhood socioeconomic status. Environ. Int. 2014, 71, 101-108. [CrossRef] [PubMed]

13. Van den Berg, M.; van Poppel, M.; van Kamp, I.; Andrusaityte, S.; Balseviciene, B.; Cirach, M.; Danileviciute, A.; Ellis, N.; Hurst, G.; Masterson, D.; et al. Visiting green space is associated with mental health and vitality: A cross-sectional study in four european cities. Health Place 2016, 38, 8-15. [CrossRef] [PubMed]

14. Jilcott, S.B.; Evenson, K.R.; Laraia, B.A.; Ammerman, A.S. Peer Reviewed: Association between Physical Activity and Proximity to Physical Activity Resources among Low-Income, Midlife Women. Prev. Chron. Dis 2007, 4, A04. Available online: https://www.ncbi.nlm.nih.gov/pmc/articles/PMC1832127/ (accessed on 28 August 2017).

15. Ries, A.V.; Voorhees, C.C.; Roche, K.M.; Gittelsohn, J.; Yan, A.F.; Astone, N.M. A Quantitative Examination of Park Characteristics Related to Park Use and Physical Activity Among Urban Youth. J. Adolesc. Health 2009, 45, S64-S70. [CrossRef] [PubMed]

16. Hagstromer, M.; Ainsworth, B.E.; Oja, P.; Sjostrom, M. Comparison of a subjective and an objective measure of physical activity in a population sample. J. Phys. Act. Health 2010, 7, 541-550. [CrossRef] [PubMed]

17. Prince, S.A.; Adamo, K.B.; Hamel, M.; Hardt, J.; Connor Gorber, S.; Tremblay, M. A comparison of direct versus self-report measures for assessing physical activity in adults: A systematic review. Int. J. Behav. Nutr. Phys. Act. 2008, 5, 56. [CrossRef] [PubMed]

18. Hartig, T.; Mitchell, R.; de Vries, S.; Frumkin, H. Nature and Health. Annu. Rev. Public Health 2014, 35, 207-228. [CrossRef] [PubMed]

19. Grahn, P.; Stigsdotter, U.A. Landscape planning and stress. Urban For. Urban Green. 2003, 2, 1-18. [CrossRef]

20. Jones, A.; Hillsdon, M.; Coombes, E. Greenspace access, use, and physical activity: Understanding the effects of area deprivation. Prev. Med. 2009, 49, 500-505. [CrossRef] [PubMed]

21. Neuvonen, M.; Sievänen, T.; Tönnes, S.; Koskela, T. Access to green areas and the frequency of visits-A case study in Helsinki. Urban For. Urban Green. 2007, 6, 235-247. [CrossRef]

22. Rossi, S.D.; Byrne, J.A.; Pickering, C.M. The role of distance in peri-urban national park use: Who visits them and how far do they travel? Appl. Geogr. 2015, 63, 77-88. [CrossRef]

23. Schipperijn, J.; Ekholm, O.; Stigsdotter, U.K.; Toftager, M.; Bentsen, P.; Kamper-Jørgensen, F.; Randrup, T.B. Factors influencing the use of green space: Results from a Danish national representative survey. Landsc. Urban Plan. 2010, 95, 130-137. [CrossRef]

24. Schipperijn, J.; Stigsdotter, U.K.; Randrup, T.B.; Troelsen, J. Influences on the use of urban green space-A case study in Odense, Denmark. Urban For. Urban Green. 2010, 9, 25-32. [CrossRef]

25. Evenson, K.R.; Wen, F.; Hillier, A.; Cohen, D.A. Assessing the Contribution of Parks to Physical Activity Using Global Positioning System and Accelerometry. Med. Sci. Sports Exerc. 2013, 45, 1981-1987. [CrossRef] [PubMed]

26. World Health Organization. Global Recommendations on Physical Activity for Health; World Health Organization: Geneva, Switzerland, 2010.

27. Kaczynski, A.T.; Henderson, K.A. Parks and Recreation Settings and Active Living: A Review of Associations with Physical Activity Function and Intensity. J. Phys. Act. Health 2008, 5, 619-632. Available online: http:/ / search.ebscohost.com/login.aspx?direct=true\&profile=ehost\&scope=site\&authtype=crawler\& jrnl=15433080\&AN=32759717\&h=vWdjtypSNT\%2BcAaP0MAjzo3kYArrPoFISX58YS9uSmCCpap\%2Fr\% 2FFWSiB1txNiEIgL18kIrTB4yk\%2BLqRnV1UQj\%2FCQ\%3D\%3D\&crl=c (accessed on 21 May 2014). [CrossRef] [PubMed]

28. Lachowycz, K.; Jones, A.P. Greenspace and obesity: A systematic review of the evidence: Greenspace and obesity review. Obes. Rev. 2011, 12, e183-e189. [CrossRef] [PubMed]

29. Bancroft, C.; Joshi, S.; Rundle, A.; Hutson, M.; Chong, C.; Weiss, C.C.; Genkinger, J.; Neckerman, K.; Lovasi, G. Association of proximity and density of parks and objectively measured physical activity in the United States: A systematic review. Soc. Sci. Med. 2015, 138, 22-30. [CrossRef] [PubMed] 
30. Sallis, J.F.; Cerin, E.; Conway, T.L.; Adams, M.A.; Frank, L.D.; Pratt, M.; Salvo, D.; Schipperijn, J.; Smith, G.; Cain, K.L. Physical activity in relation to urban environments in 14 cities worldwide: A cross-sectional study. Lancet 2016, 387, 2207-2217. [CrossRef]

31. Brownson, R.C.; Baker, E.A.; Housemann, R.A.; Brennan, L.K.; Bacak, S.J. Environmental and policy determinants of physical activity in the United States. Am. J. Public Health 2001, 91, 1995-2003. [CrossRef] [PubMed]

32. Pietilä, M.; Neuvonen, M.; Borodulin, K.; Korpela, K.; Sievänen, T.; Tyrväinen, L. Relationships between exposure to urban green spaces, physical activity and self-rated health. J. Outdoor Recreat. Tour. 2015, 10, 44-54. [CrossRef]

33. Astell-Burt, T.; Feng, X.; Kolt, G.S. Green space is associated with walking and moderate-to-vigorous physical activity (MVPA) in middle-to-older-aged adults: Findings from 203883 Australians in the 45 and Up Study. Br. J. Sports Med. 2014, 48, 404-406. [CrossRef] [PubMed]

34. Bjork, J.; Albin, M.; Grahn, P.; Jacobsson, H.; Ardo, J.; Wadbro, J.; Östergren, P.-O.; Skärbäck, E. Recreational values of the natural environment in relation to neighbourhood satisfaction, physical activity, obesity and wellbeing. J. Epidemiol. Community Health 2008, 62, e2. [CrossRef] [PubMed]

35. Janssen, I.; Rosu, A. Undeveloped green space and free-time physical activity in 11 to 13-year-old children. Int. J. Behav. Nutr. Phys. Act. 2015, 12, 26. [CrossRef] [PubMed]

36. McMorris, O.; Villeneuve, P.J.; Su, J.; Jerrett, M. Urban greenness and physical activity in a national survey of Canadians. Environ. Res. 2015, 137, 94-100. [CrossRef] [PubMed]

37. Ord, K.; Mithcell, R.; Pearce, J. Is level of neighbourhood green space associated with physical activity in green space? Int. J. Behav. Nutr. Phys. Act. 2013, 10, 127. [CrossRef] [PubMed]

38. Richardson, E.A.; Pearce, J.; Mitchell, R.; Kingham, S. Role of physical activity in the relationship between urban green space and health. Public Health 2013, 127, 318-324. [CrossRef] [PubMed]

39. Sanders, T.; Feng, X.; Fahey, P.P.; Lonsdale, C.; Astell-Burt, T. The Influence of neighbourhood Green Space on Children's Physical Activity and Screen Time: Findings from the Longitudinal Study of Australian Children. Int. J. Behav. Nutr. Phys. Act. 2015, 12, 126. Available online: http://www.ijbnpa.org/content/12/1/126 (accessed on 3 December 2015). [CrossRef] [PubMed]

40. Klinker, C.D.; Schipperijn, J.; Kerr, J.; ErsbÃ_ll, A.K.; Troelsen, J. Context-Specific Outdoor Time and Physical Activity among School-Children Across Gender and Age: Using Accelerometers and GPS to Advance Methods. Front. Public Health 2014, 2, 20. Available online: http:/ /www.frontiersin.org/Public_Health_ Education_and_Promotion/10.3389/fpubh.2014.00020/abstract (accessed on 29 July 2014). [CrossRef] [PubMed]

41. Lachowycz, K.; Jones, A.P.; Page, A.S.; Wheeler, B.W.; Cooper, A.R. What can global positioning systems tell us about the contribution of different types of urban greenspace to children's physical activity? Health Place 2012, 18, 586-594. [CrossRef] [PubMed]

42. Liao, Y.; Intille, S.S.; Dunton, G.F. Using Ecological Momentary Assessment to Understand Where and With Whom Adults' Physical and Sedentary Activity Occur. Int. J. Behav. Med. 2015, 22, 51-61. [CrossRef] [PubMed]

43. Schipperijn, J.; Bentsen, P.; Troelsen, J.; Toftager, M.; Stigsdotter, U.K. Associations between physical activity and characteristics of urban green space. Urban For. Urban Green. 2013, 12, 109-116. [CrossRef]

44. Mitchell, R. Is physical activity in natural environments better for mental health than physical activity in other environments? Soc. Sci. Med. 2013, 91, 130-134. [CrossRef] [PubMed]

45. Thompson Coon, J.; Boddy, K.; Stein, K.; Whear, R.; Barton, J.; Depledge, M.H. Does Participating in Physical Activity in Outdoor Natural Environments Have a Greater Effect on Physical and Mental Wellbeing than Physical Activity Indoors? A Systematic Review. Environ. Sci. Technol. 2011, 45, 1761-1772. [CrossRef] [PubMed]

46. Pasanen, T.P.; Tyrväinen, L.; Korpela, K.M. The Relationship between Perceived Health and Physical Activity Indoors, Outdoors in Built Environments, and Outdoors in Nature: Perceived Health and Activity in Nature. Appl. Psychol. Health Well-Being 2014, 6, 324-346. [CrossRef] [PubMed]

47. Ou, J.; Levy, J.; Peters, J.; Bongiovanni, R.; Garcia-Soto, J.; Medina, R.; Scammell, M.K. A Walk in the Park: The Influence of Urban Parks and Community Violence on Physical Activity in Chelsea, MA. Int. J. Environ. Res. Public Health 2016, 13, 97. [CrossRef] [PubMed] 
48. Nieuwenhuijsen, M.J.; Kruize, H.; Gidlow, C.; Andrusaityte, S.; Antó, J.M.; Basagaña, X.; Cirach, M.; Dadvand, P.; Danileviciute, A.; Donaire-Gonzalez, D. Positive health effects of the natural outdoor environment in typical populations in different regions in Europe (PHENOTYPE): A study programme protocol. BMJ Open 2014, 4, e004951. [CrossRef] [PubMed]

49. Donaire-Gonzalez, D.; Valentín, A.; de Nazelle, A.; Ambros, A.; Carrasco-Turigas, G.; Seto, E.; Jerrett, M.; Nieuwenhuijsen, M.J. Benefits of Smartphone Technology for Personal Environmental Monitoring. JMIR MHealth UHealth 2016, 4, e126. [CrossRef] [PubMed]

50. Donaire-Gonzalez, D.; de Nazelle, A.; Seto, E.; Mendez, M.; Nieuwenhuijsen, M.J.; Jerrett, M. Comparison of Physical Activity Measures Using Mobile Phone-Based CalFit and Actigraph. J. Med. Internet Res. 2013, 15, e111. [CrossRef] [PubMed]

51. Heil, D.P.; Brage, S.; Rothney, M.P. Modeling Physical Activity Outcomes from Wearable Monitors. Med. Sci. Sports Exerc. 2012, 44, S50-S60. [CrossRef] [PubMed]

52. Matthews, C.E.; HagströMer, M.; Pober, D.M.; Bowles, H.R. Best Practices for Using Physical Activity Monitors in Population-Based Research. Med. Sci. Sports Exerc. 2012, 44, S68-S76. [CrossRef] [PubMed]

53. Gascon, M.; Triguero-Mas, M.; Martínez, D.; Dadvand, P.; Forns, J.; Plasència, A.; Nieuwenhuijsen, M.J. Mental Health Benefits of Long-Term Exposure to Residential Green and Blue Spaces: A Systematic Review. Int. J. Environ. Res. Public Health 2015, 12, 4354-7439. [CrossRef] [PubMed]

54. European Environment Agency. Urban Atlas (Internet). 2014. Available online: http://www.eea.europa.eu/ data-and-maps / data/urban-atlas/\#parent-fieldname-title (accessed on 21 January 2015).

55. The Netherlands' Cadastre. Land Registry and Mapping Agency. Information on Kadaster. TOP10NL (Internet). Available online: http:/ / www.kadaster.nl/web/artikel/producten/TOP10NL.htm (accessed on 21 January 2015).

56. Carlson, J.A.; Sallis, J.F.; Conway, T.L.; Saelens, B.E.; Frank, L.D.; Kerr, J.; Cain, K.L.; King, A.C. Interactions between psychosocial and built environment factors in explaining older adults' physical activity. Prev. Med. 2012, 54, 68-73. [CrossRef] [PubMed]

57. Coombes, E.; Jones, A.P.; Hillsdon, M. The relationship of physical activity and overweight to objectively measured green space accessibility and use. Soc. Sci. Med. 2010, 70, 816-822. [CrossRef] [PubMed]

58. Toohey, A.M.; McCormack, G.R.; Doyle-Baker, P.K.; Adams, C.L.; Rock, M.J. Dog-walking and sense of community in neighborhoods: Implications for promoting regular physical activity in adults 50 years and older. Health Place 2013, 22, 75-81. [CrossRef] [PubMed]

59. Saelens, B.E.; Sallis, J.F.; Frank, L.D.; Cain, K.L.; Conway, T.L.; Chapman, J.E.; Slymen, D.; Kerr, J. Neighborhood Environment and Psychosocial Correlates of Adults' Physical Activity. Med. Sci. Sports Exerc. 2012, 44, 637-646. [CrossRef] [PubMed]

60. Kaczynski, A.T.; Potwarka, L.R.; Smale, B.J.A.; Havitz, M.E. Association of Parkland Proximity with Neighborhood and Park-based Physical Activity: Variations by Gender and Age. Leis. Sci. 2009, 31, 174-191. [CrossRef]

61. Gilchrist, K.; Brown, C.; Montarzino, A. Workplace settings and wellbeing: Greenspace use and views contribute to employee wellbeing at peri-urban business sites. Landsc. Urban Plan. 2015, 138, 32-40. [CrossRef]

62. Freedson, P.; Melanson, E.; Sirard, J. Calibration of the Computer Science and Apllications, Inc. accelerometer. Med. Sci. Sports Exerc. 1998, 30, 777-781. [CrossRef] [PubMed]

(C) 2017 by the authors. Licensee MDPI, Basel, Switzerland. This article is an open access article distributed under the terms and conditions of the Creative Commons Attribution (CC BY) license (http://creativecommons.org/licenses/by/4.0/). 